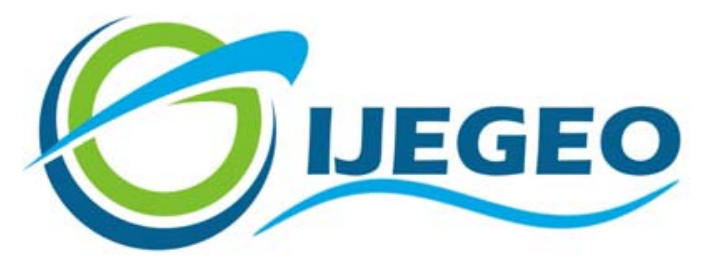

International Journal of Environment and Geoinformatics (IJEGEO) is an international, multidisciplinary, peer reviewed, open access journal.

\title{
Investigation of Climate Change Impact on Salt Lake by Statistical Methods
}

\section{Osman Orhan, Sefa Yalvaç and Semih Ekercin}

\section{Editors}

Prof. Dr. Cem Gazioğlu, Prof. Dr. Dursun Zafer Şeker, Prof. Dr. Ayşegül Tanık, Assoc. Prof. Dr. Şinasi Kaya

\section{Guest Editors}

Assoc. Prof. Dr. Ekrem Tuşat, Asist. Prof. Dr. Fatih Sarı, Prof. Dr. Hakan Karabörk

\section{Scientific Committee}

Assoc. Prof. Dr. Hasan Abdullah (BL), Assist. Prof. Dr. Alias Abdulrahman (MAL), Assist. Prof. Dr. Abdullah Aksu, (TR); Prof. Dr. Hasan Atar (TR), Prof. Dr. Lale Balas (TR), Prof. Dr. Levent Bat (TR), Assoc. Prof. Dr. Füsun Balık Şanlı (TR), Prof. Dr. Nuray Balkıs Çağlar (TR), Prof. Dr. Bülent Bayram (TR), Prof. Dr. Şükrü T. Beşiktepe (TR), Dr. Luminita Buga (RO), Prof. Dr. Z. Selmin Burak (TR), Assoc. Prof. Dr. Gürcan Büyüksalih (TR), Dr. Jadunandan Dash (UK), Assist. Prof. Dr. Volkan Demir (TR), Assoc. Prof. Dr. Hande Demirel (TR), Assoc. Prof. Dr. Nazlı Demirel (TR), Dr. Arta Dilo (NL), Prof. Dr. A. Evren Erginal (TR), Dr. Alessandra Giorgetti (IT), Assoc. Prof. Dr. Murat Gündüz (TR), Prof. Dr. Taşkın Kavzoğlu (TR), Dr. Hakan Kaya (TR), Assoc. Prof. Dr. Kensuke Kawamura (JAPAN), Prof. Dr. Fatmagül Kılıç (TR), Prof. Dr. Ufuk Kocabaş (TR), Prof. Dr. Hakan Kutoğlu (TR), Prof. Dr. Nebiye Musaoğlu (TR), Prof. Dr. Erhan Mutlu (TR), Assist. Prof. Dr. Hakan Öniz (TR), Assoc. Prof. Dr. Hasan Özdemir (TR), Prof. Dr. Haluk Özener (TR), Assoc. Prof. Dr. Barış Salihoğlu (TR), Prof. Dr. Elif Sertel (TR), Prof. Dr. Murat Sezgin (TR), Prof. Dr. Nüket Sivri (TR), Assoc. Prof. Dr. Uğur Şanlı (TR), Assoc. Prof. Dr. Seyfettin Taş (TR), Assoc. Prof. Dr. İ. Noyan Yılmaz (TR), Assist. Prof. Dr. Baki Yokeş (TR), Assist. Prof. Dr. Sibel Zeki (TR). 


\section{Dear colleagues;}

We are very glad to meet you with "International Journal of Environment and Geoinformatics" special issue which is a compilation of proceedings presented in "SELÇUK INTERNATIONAL SCIENTIFIC CONFERENCE ON APPLIED SCIENCES" held on 27-30 September in Antalya/Turkey.

Besides Turkish scientists, The Selçuk ISCAS 2016 brought together Russian, Ukrainian, Kazakhstan, Azerbaijani, Persian, Algerian, Nigerian, Netherlander, Scottish, Liberian, Philippines and Czech Republican scientists. Turkey General Directorate of Land Registry and Cadastre, Republic of Turkey Ministry of Food, Agriculture and Livestock Undersecretary, International Federal of Surveyors (FIG) and International Society for Photogrammetry and Remote Sensing (ISPRS) contribute to The Selçuk ISCAS 2016 at board of director's level.

The Selçuk International Scientific Conference on Applied Sciences (The Selçuk ISCAS 2016) held in Antalya on 27-30, September 2016. The Selçuk ISCAS 2016 is a candidate of one of the most important event in the scientific schedule and tenders a possibility for researchers and academicians who researches on applied sciences. You can find a first class programme of plenary speakers, technical sessions, exhibitions and social events in this book. You will be able to catch up with the developments in Geographical Information Sciences, Information Technology, Environmental Management and Resources, Sustainable Agriculture, Surveying, Photogrammetry and Remote Sensing, meet friends and experience the traditional and fascinating culture of TURKIYE. As an international conference in the field of geo-spatial information and remote sensing, The Selçuk ISCAS 2016 is devoted to promote the advancement of knowledge, research, development, education and training in Geographical Information Sciences, Information Technology, Environmental Management and Resources, Sustainable Agriculture, Surveying, Photogrammetry and Remote Sensing, their integration and applications, as to contribute to the well-being of humanity and the sustainability of the environment. The Conference of Selçuk ISCAS 2016 will provide us an opportunity to examine the challenges facing us, discuss how to support Future Earth with global geo-information, and formulate the future research agenda.

195 scientists from 13 countries attended to the symposium. 105 oral presentations, 40 fast oral presentations and 50 poster presentations are presented during the symposium. 145 oral and fast oral presentations take place in 24 technical sessions in two days. On the other hand, 5 invited speaker presentations held in the plenary session in the first day.

The conference is carried out with the support of the organizations as the Selçuk University, General Directorate of Land Registry and Cadastre, General Directorate Of Agricultural Reform, Turkish Cooperation and Development Agency (TIKA), International Federation of Surveyors (FIG) and International Society for Photogrammetry and Remote Sensing (ISPRS). In addition, the symposium is also supported by the commercial organizations of Paksoyteknik, Mescioğlu, Geogis, Körfez, Tümaş, 4B Ölçüm, GNSS Teknik, Arbiotek ve Anıt Hospital.

Best wishes.

Assoc. Prof. Dr. Ekrem Tuşat

Asist. Prof. Dr. Fatih Sarı

Prof. Dr. Hakan Karabörk 


\title{
Investigation of Climate Change Impact on Salt Lake by Statistical Methods
}

\author{
Osman Orhan ${ }^{1, *}$, Sefa Yalvaç ${ }^{1}$ and Semih Ekercin ${ }^{2}$ \\ ${ }^{1}$ Selçuk University, Engineering Faculty, Department of Geomatic Engineering, 42075 Konya, TR \\ ${ }^{2}$ Aksaray University, Department of Geomatic Engineering,68100 Aksaray,TR
}

\begin{abstract}
The main purpose of this paper is to investigate climate change impact that have been occurred on Salt Lake located in the central Anatolia is one of the area that has been faced to extinction. In order to monitor current status of the Salt Lake, Landsat satellite images has been obtained between the year of 2000 and 2014 (for the months of February, May, August and November). Satellite images has been processed by using ArcGIS and ERDAS softwares and the water surface area has been determined. The time series of water surface areas has been analyzed with auto-correlation method and repeated pattern has been detected. The seasonal part of the time series which period is 1 year and causes about $400 \mathrm{~km}^{2}$ fluctuations has been removed with Moving Average filter, successfully. As a result of filtration process, non-seasonal time series of water surface area of Salt Lake were obtained. It is understood from the non-seasonal time series that the water surface area showed variability between 2000 and 2010 and after 2010 it is stable until 2014. In order to explain the variability, meteorological data (precipitation and temperature) of the surrounding area has been acquired from the related service. The cross-correlation analyses has been performed with the movement of the water surface area and meteorological time series. As a result of analysis, the relationship between water surface changes in Salt Lake and meteorological data have correlated up to $80 \%$. Consequently, several conclusion have been detected that the topography of the region play a direct role of the correlation coefficients and the water surface changes are effected from the environmental events that is occurred in the south of Salt Lake sub-Basin.
\end{abstract}

Keywords: Salt Lake, Climate Change, Shrinkage of lake, Correlation Analysis, Moving Average Filter.

\section{Introduction}

As a result of increased drought, many freshwater supplies such as lake, groundwater etc. has been reduced, excessively. As a result, many studies have been carried out in the various part of the world have report that shrinkage of lakes which is a source of water for both humans and livestock. The shrinkage of lakes represents a huge threat due to increasing drought effects and anthropogenic activities. These activities may comprise, but not limited to, land cover and land use change, uncontrolled use of groundwater, deforestation, rising water demands, urbanization, dam construction and irrigation (Orhan et al., 2014; Yıldırım et al., 2011; Du et al., 2001; Yan et al., 2002; Penny and Kealhofer, 2005; Legesse and Ayenew, 2006; Kiage et al., 2007). Temporal climatic fluctuation, especially the change of precipitation, is believed to be the major cause of lake shrinkages (Birkett, 2000; Moln'ar et al., 2002; Mercier et al., 2002; Medina et al., 2008). Increased evapotranspiration could further expand the impact of the increase in temperatures by leading to escalation of summer aridity, potential harms on forests and agricultural lands, detrimental effects on fruit trees and vineyards, and amplified need for irrigation. Therefore, large lake such as Lake Burdur shrank, and shallow lakes such as Lake Aksehir and Lake Eber vanished in Turkey (Kantarc1, 2005).

Remote sensing has been used to investigate the impacts of climate change studies for many years at local and global scale (Nagai et al., 2007; Piwowar and Ledrew, 2002 Dube, 2001). This technology has application, for instance, in identifying and quantifying areas experiencing 
drought which is one of the most important hydrological and agricultural problems in the world (Gazioğlu, et al. 2010; Simav et al., 2013). In practice, spatial and temporal comparisons can be made for specific locations and/or for certain months/seasons using multitemporal satellite data (Pozdnyakov et al., 2005).

This study has focused to explain the Salt lake shrinkage and the reasons of that problem.

\section{Methodology, Study Area}

Salt Lake is the second largest lake in Turkey, only smaller than Lake Van, lying at an elevation of $905 \mathrm{~m}$ as a tectonic lake. The lake is very shallow (about 40 centimeters), especially during dry summer months when the water evaporates in huge quantities leaving a tick crust of salt on the surface up to 30 centimeters. This salt is extracted, processed, refined and sold in the local market, thus making this the biggest industry for small towns' economy in the area. It's not only the largest salt lake of Turkey but one of the largest and most saline in the world as well. The density of the water is $1.225 \mathrm{gr} / \mathrm{cm} 3$ and salinity is $32.4 \%$. The lake has no outlet, and only few surface streams feed it. Annual rainfall in the surrounding area is as low as 300 mm (AAT, 2007).

\section{Image Processing}

In this study, a total of 56 multi-temporal and multi spectral image series were used as remotely sensed data source for the period of 2000-2014. All satellite imagery was acquired from Landsat satellites. Eight images were obtained from the Landsat Thematic Mapper (TM), forty-three images were obtained from the Landsat Enhanced Thematic Mapper plus (ETM+) and five images were obtained from Landsat 8 Operational Land Imager (OLI).
Each image, used to calculate Water surface area, presents the condition of either February, May, August or November months of each year to specify seasonal and temporal variations of Salt Lake's surface area.

Coastline changes and multitemporal water reserve changes were obtained for Salt Lake using The Normalised Difference Water Index (NDWI). NDWI is derived using similar principles to the Normalised Difference Vegetation Index (NDVI). (McFeeters, 1996). The selection of these wavelengths maximises the reflectance properties of water. That is: Maximise the typical reflectance of water features by using green wavelengths, Minimise the low reflectance of NIR by water features and Maximise the high reflectance of NIR by terrestrial vegetation and soil features. The outcomes from this equation are water features that have positive values while soil and terrestrial vegetation have zero or negative values (McFeeters, 1996).

In this study, manual onscreen digitizing was preferred to extraction water body mapping. Principal reason for preferring of manual digitization process on screen is 43 of 56 images used in this study acquired after The Landsat ETM+ Scan Line Corrector (SLC) failed, causing the scanning pattern to exhibit wedge-shaped scan- to-scan gaps, on 31 May 2003. The size of the study area and having linear boundaries of Salt lake additionally is other reasons for preferring this method.

\section{Corelation}

In statistics, dependence or association is any statistical relationship between two random variables or two sets of data. Correlations are useful for applied sciences in order to estimate the dependence between two environmental variables with one another (Dunn ,2014). 

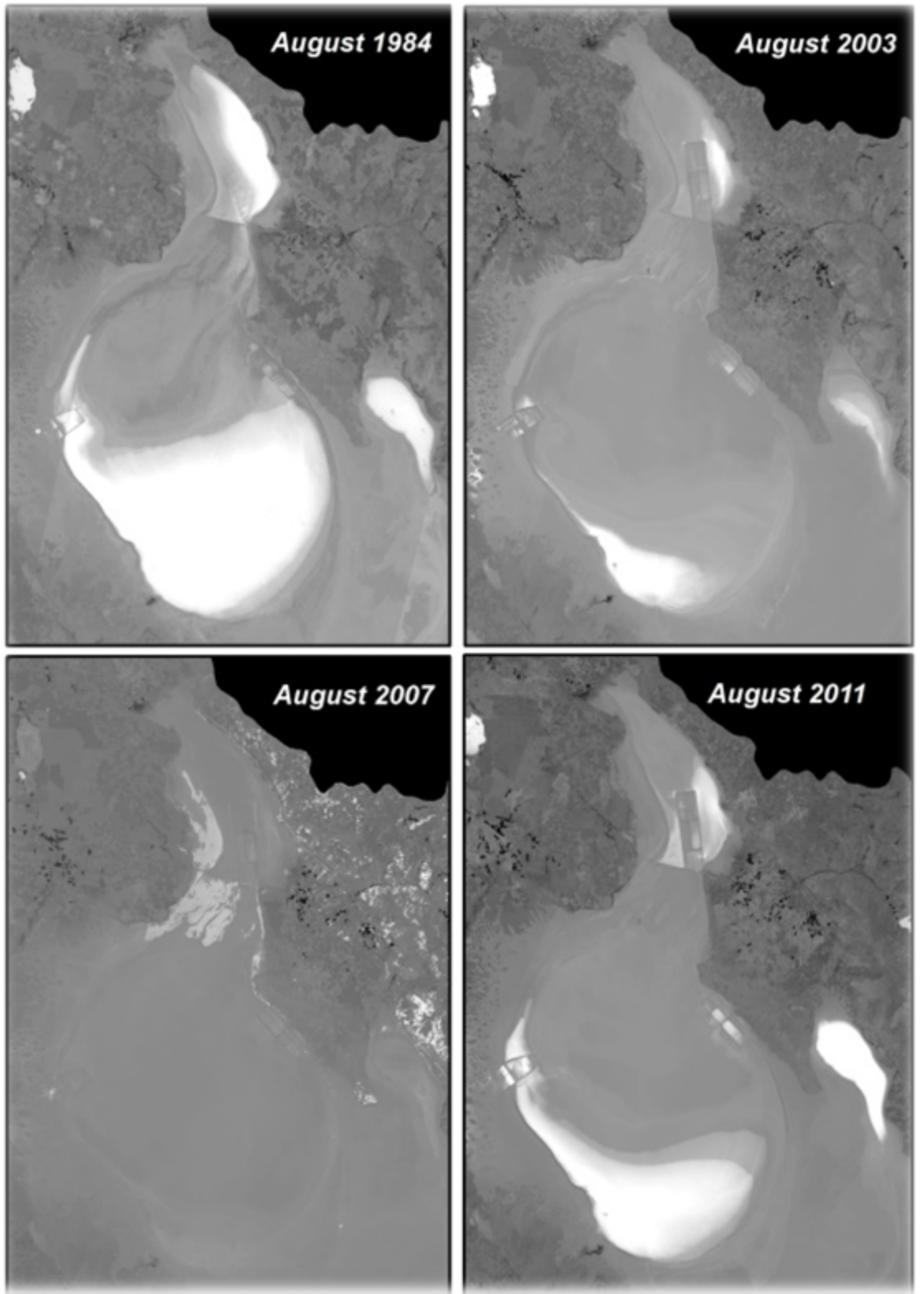

Figure 1. Examples of the Salt Lake for NDWI 
Cross correlation is a standard method of estimating the degree to which two series are correlated. Consider two series $\mathrm{x}(\mathrm{i})$ and $\mathrm{y}(\mathrm{i})$ where $i=0,1,2 \ldots \mathrm{N}-1$. The cross correlation " $r$ " at delay " $d$ " is defined as;

$\mathrm{rxy}=\frac{\sum_{\mathrm{i}}\left(\mathrm{x}_{\mathrm{i}}-\mathrm{m}_{\mathrm{x}}\right)\left(\mathrm{y}_{\mathrm{i}-\mathrm{d}}-\mathrm{m}_{\mathrm{y}}\right)}{\sigma_{\mathrm{x}} \sigma_{\mathrm{y}}}$

Where $\mathrm{mx}$ and my are the means of the corresponding series. If the above is computed for all delays $d=0,1,2, \ldots \mathrm{N}-1$ then it results in a cross correlation series (correlogram) of twice the length as the original series.

As the the autocorrelation can be expressed as a function of the time-lag with the time series own data with the delay, the given formula can be replaced with;

$\mathrm{rx}=\frac{\sum_{\mathrm{i}}\left(\mathrm{x}_{\mathrm{i}}-\mathrm{m}_{\mathrm{x}}\right)\left(\mathrm{x}_{\mathrm{i}-\mathrm{d}}-\mathrm{m}_{\mathrm{x}}\right)}{\sigma_{\mathrm{x}^{2}}}$

\section{Moving Average Filter}

There are several ways to reducing seasonality from the time series such as differencing method, logarithmic transformation and moving average filter for the data on time domain. But, if the period of the time series is known, the moving average filter has generally preferred (Yalvac, 2016).

In statistics, a moving average (rolling average or running average) is a calculation to analyze data points by creating series of averages of different subsets of the full data set. It is also called a moving mean (MM) or rolling mean and is a type of finite impulse response filter (Booth et al.). The definition of $\mathrm{M}$ sample size of a simple Moving Average (MA) filter is:

$\mathrm{MA}=\frac{1}{\mathrm{n}} \sum_{\mathrm{i}=0}^{\mathrm{i}-1} \mathrm{p}_{\mathrm{M}-\mathrm{i}}=\frac{\mathrm{p}_{\mathrm{M}}+\mathrm{P}_{\mathrm{M}-1}+. .+\mathrm{P}_{\mathrm{M}-(\mathrm{n}-1)}}{\mathrm{n}}$

In eq (3), $\mathrm{n}$ indicates the Moving Average sample size and $\mathrm{P}$ shows the each sample of the time series. In order to reduce seasonality on a time series, $\mathrm{n}$ should be chosen as a period of the time series which has been estimated via autocorrelation analyses.

As seen from Figure 2, the water surface area time series which obtained from remote sensing techniques contain periodic fluctuations. The period of the fluctuation has been estimated one year (4 samples) by using autocorrelation analyses (Figure 3). It is thought that this periodicity caused by annual rainfall similarity and it is called as seasonal effect.

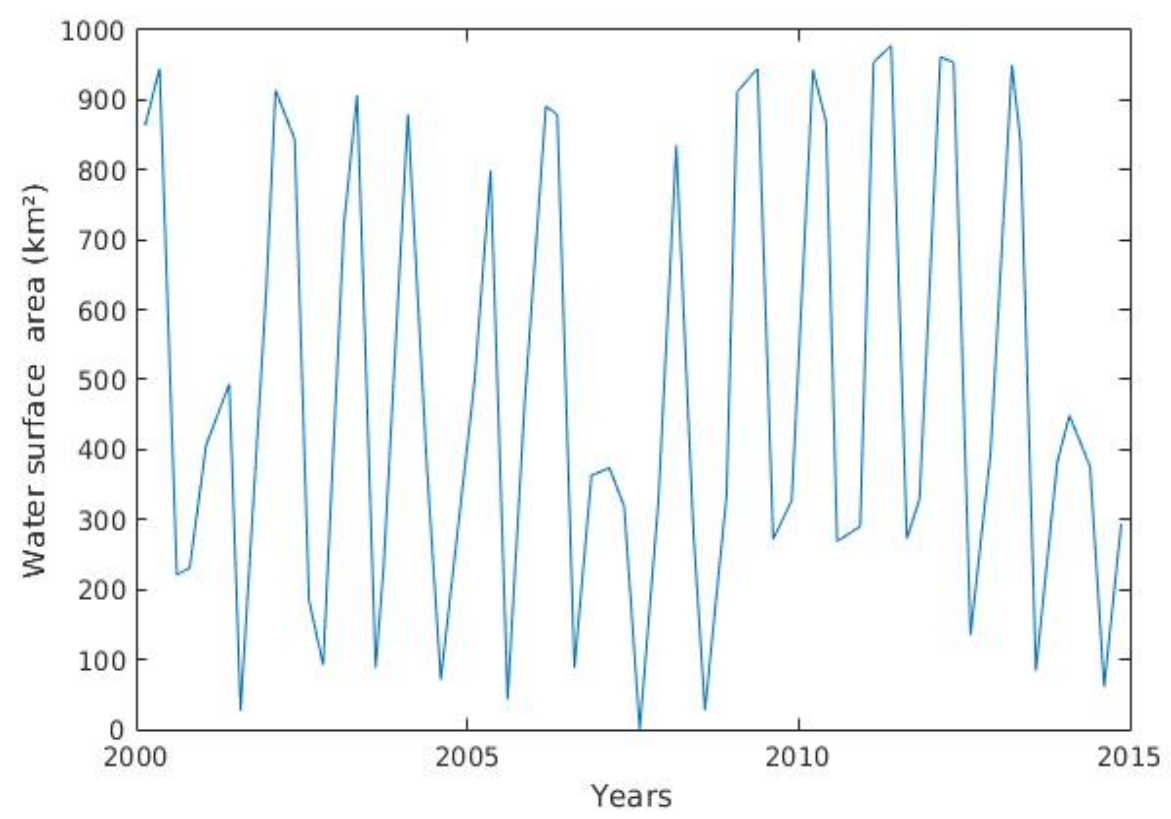

Figure 2: Time series of water surface area derived from remote sensing technique. 


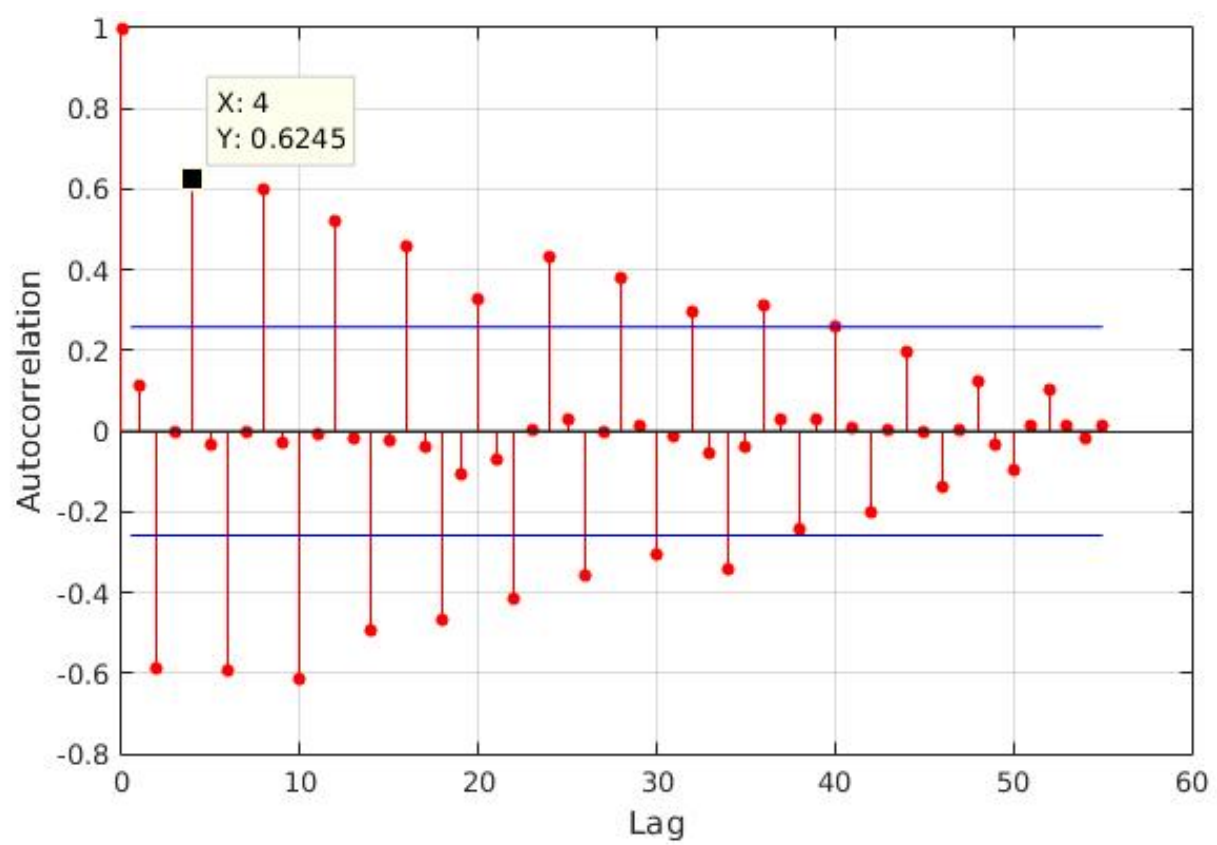

Figure 3: Correlogram of time series data of water surface by means of autocorrelation analyses.

from Figure 4 that the water surface decreased about $400 \mathrm{~km}^{2}$ between the years of 2000-2002.

The seasonal effect has been detected and removed from the time series by means of moving average filter. As seen from figure 4, while the blue line indicates the raw time series, the red line shows the filtered (non-seasonal) data. Filtered data gives information about the changes Salt lake water surface area between the year of 2000 and 2015. It can be concluded

Then, it remained constant during the 2002 to 2006. After 2006, it decreased about $300 \mathrm{~km}^{2}$ and falling to the level of $290 \mathrm{~km}^{2}$. During the 2006 to 2007, the water surface uplift to 600 $\mathrm{km}^{2}$ and it was followed stable until 2014. Last year, again it fell to the level of $300 \mathrm{~km}^{2}$.

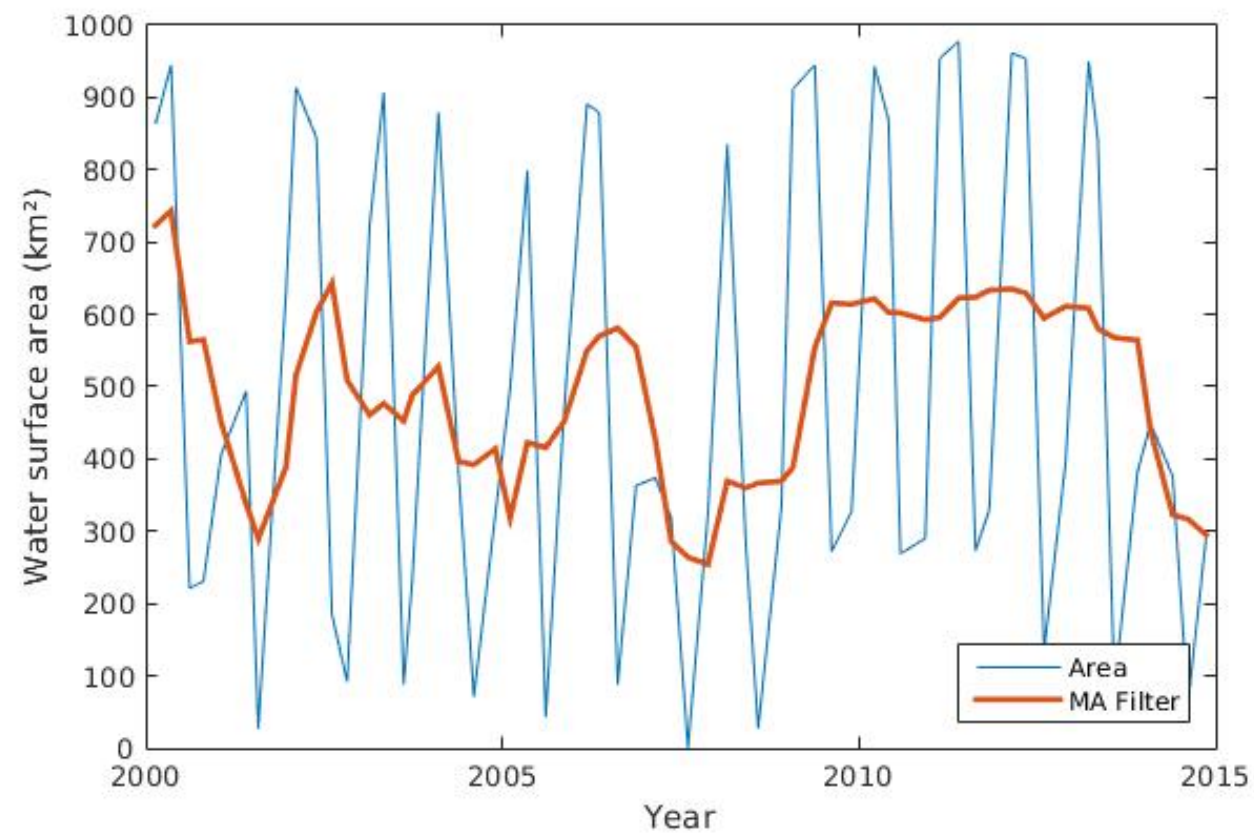

Figure 4: Raw and filtered (non-seasonal) time series of water surface area data 
In order to estimate the correlation between water surface area and precipitation, crosscorrelation analyses has been carried out. For this purpose, precipitation data has been obtained from the observation station near the Salt lake between the year of 2000-2013. Total annual of the rainfall has been calculated for each year and analyzed with water surface area by means of cross-correlation analyses. The correlograms for Aksaray and Cumra (highest and lowest cross-correlation values) precipitation observations stations have been shown on Figure 5 and Table 1 shows the cross correlation values numerically.

In figure 5, blue line indicates the confidence interval and a peak (0.77) is seen for the Aksaray stations on lag 0 which cross the confidence level ( 0.58 for the 14 samples). The correlograms for the cihanbeyli and nigde also similar with Aksaray. Unlike Aksaray, Cihanbeyli and Nigde, all of the sample of Cumra station are nearly 0.2 that are below the confidence level. This situation is nearly same for the stations which have low crosscorrelation value.

Table 1. Table of Confidence level

\begin{tabular}{|l|l|}
\hline \multicolumn{2}{|l|}{ Correlation Value } \\
\hline Aksaray & 0.773 \\
\hline Cihanbeyli & 0.6 \\
\hline Beyşehir & 0.2 \\
\hline Ereğli & 0.42 \\
\hline Karaman & 0.41 \\
\hline Kulu & 0.15 \\
\hline Karapınar & 0.1 \\
\hline Niğde & 0.68 \\
\hline Seydisehir & 0.32 \\
\hline Çumra & 0.1 \\
\hline Konya & 0.40 \\
\hline
\end{tabular}

\section{Conclusion}

Correlations are statistical tools that can be used easily in the study of environmental issues, which depend on many external factors. By processing the correlation coefficients, the relationship of environmental variables with each other will be revealed. Thus, in light of external factors, environmental events will be more accurate with watch from a broad perspective.

Especially, meteorological events such as rainfall affected by environmental events include seasonal effects due to the meteorological events repeating every year. In this study, seasonal effect was determined using the auto-correlation analysis in water surface area series. The effect, identified as 1 year, has been removed from the time series. Using Moving Average filter. Thus changes in water surface area has been demonstrated over the years by purified time series from seasonal fluctuations.

When the correlations are examined, water surface area of the salt lake has been found to be directly related to meteorological events. So precipitation seen in Aksaray, Nigde, Cihanbeyli (in conjunction with topography) has been found to be associated with the level of $80 \%$ with the change in the salt lake area. Meteorological monitoring stations in the region should be examined to monitoring changes in the salt lake area. Area change is not only related to precipitation. Therefore changes of the Salt lake area will be compared with temperature ground water etc. in further studies. 

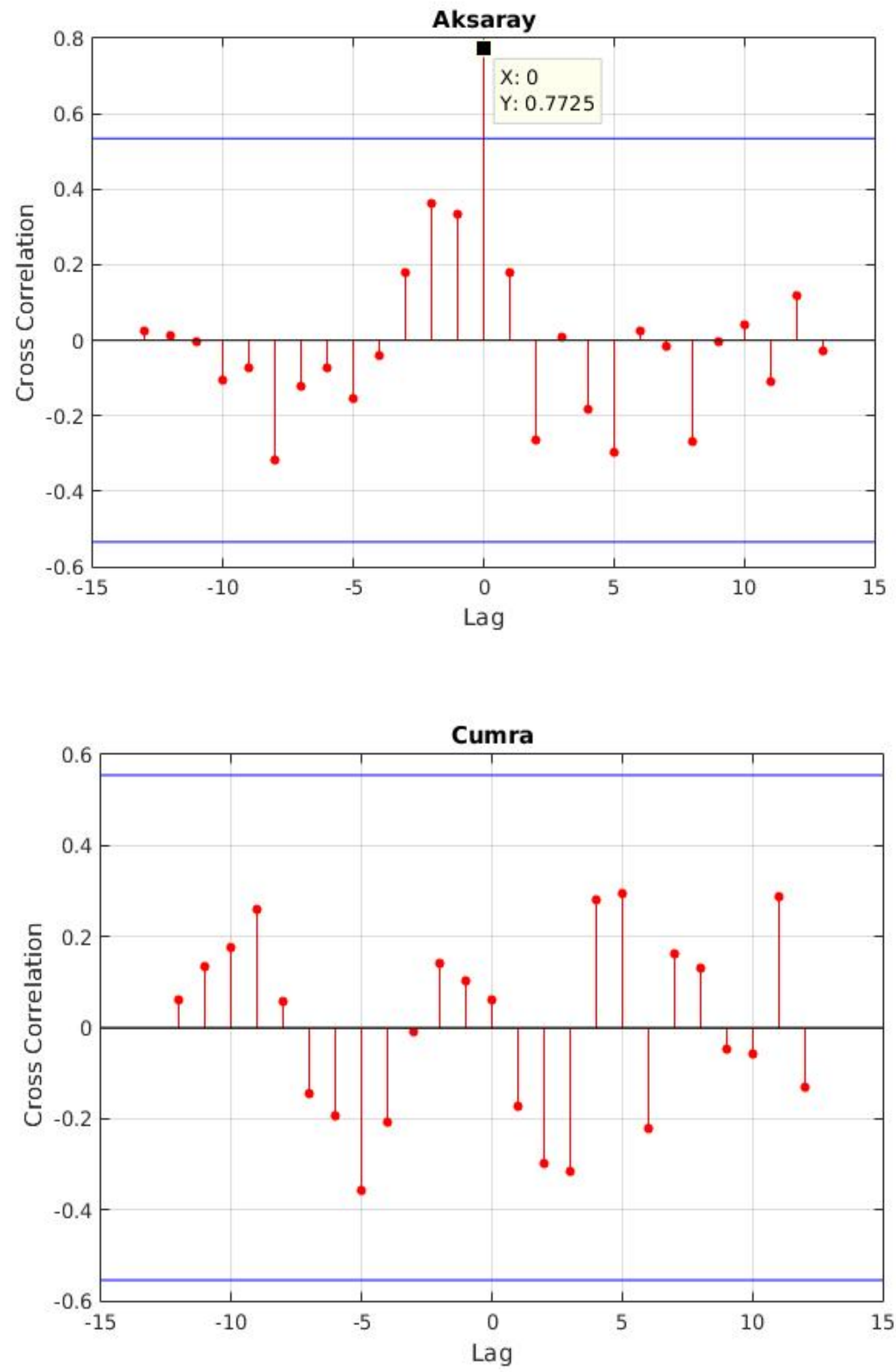

Figure 5: Cross-correlation correlograms for Aksaray and Cumra precipitation observation stations. 


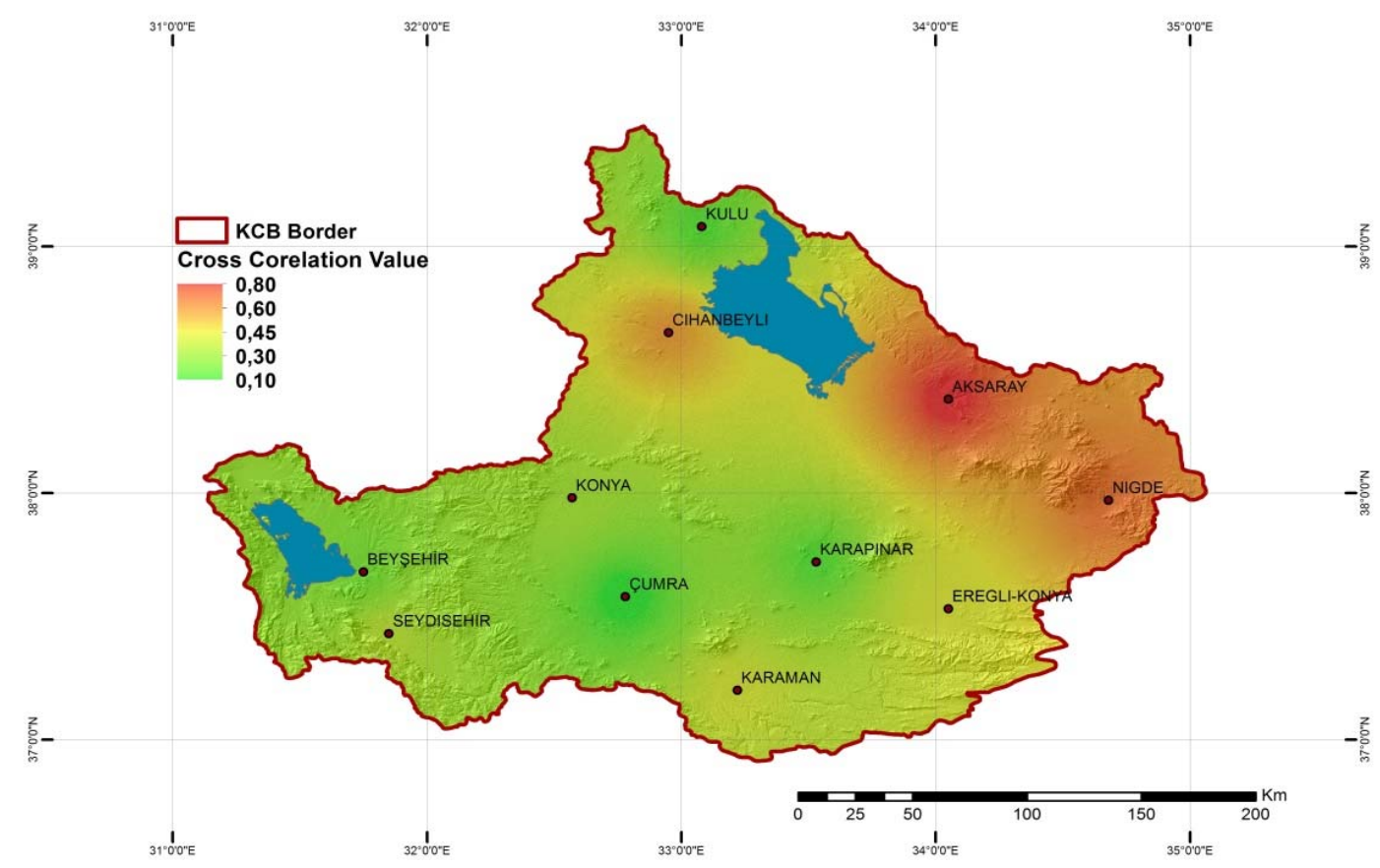

Figure 6: Map showing the relationship of the meteorological stations.

\section{References}

AAT.(2007): All About Turkey. Available at: http://www.allaboutturkey.com/tuzlake.htm, (Accessed 27.11.2014).

Birkett, C.M. (2000): Synergistic remote sensing of Lake Chad: variability of basin inundation. Remote Sens Environ. 72: 218236.

Booth, E., Mount, J. and Viers, J. H. (2006): Hydrologic variability of the Cosumnes River floodplain. San Francisco Estuary and Watershed Science, 4(2):1-19.

Du, Y., Cai, S., Zhang and X., Zhao, Y.(2001): Interpretation of the environmental change of Dongting Lake, middle reach of Yangtze River, China, by $210 \mathrm{~Pb}$ measurement and satellite image analysis. Geomorphology. 41:171-181.

Dube, O. (2001): Remote sensing, climate change and landuse impacts in semi-arid lands of Southern Africa. Geoscience and Remote Sensing Symposium, 2001. IGARSS apos;01. IEEE 2001 International. 6: 2686-2688.
Dunn, P. F. (2014). Measurement and data analysis for engineering and science. CRC press.

Gazioğlu C., Burak,S., Alpar, B., Türker, A. and Barut, IF. (2010): Foreseeable impacts of sea level rise on the southern coast of the Marmara Sea (Turkey), Water Policy.Vol.12(6): 932-943.

Kantarci, M. D. (2005): Forest ecosystems knowledge, Istanbul University published book no: 4594. Forest Faculty published no: 488, Istanbul (in Turkish).

Kiage, L.M., Liu, K.B., Walker, N.D., Lam, N. and Huh, O.K. (2007): Recent landcover/use change associated with land degradation in the Lake Baringo catchment, Kenya, East Africa: evidence from Landsat $\mathrm{TM}$ and $\mathrm{ETM}+$. Int $\mathrm{J}$ Remote Sens. 28(19),4285-4309.

Legesse, D. and Ayenew, T. (2006): Effect of improper water and land resource utilization on the central main Ethiopian rift lakes. Quat Int. 148,8-18.

Mcfeeters, S.K. (1996): The use of normalized difference water index (NDWI) in the delineation of open water features. 
International Journal of Remote Sensing. 17:1425-1432.

Medina, C.E., Enri, J.G. and Villares, A.P. (2008): Water level fluctuations derived Ftom ENVISAT Radar Altimeter (RA-2) and in-situ measurements in subtropical waterbody: Lake Izabel (Guatemala). Remote Sens Environ. 112: 3604-3617.

Mercier, F., Cazenave, A. and Maheu, C. (2002): Interannual lake level fluctuations (1993-1999) in Africa from Topex/Poseidon: connections with oceanatmosphere interactions over the Indian Ocean. Glob Planet Changes. 32:141-163.

Moln'ar, P., Burlando, P. and Ruf, W.(2002): Integrated catchment assessment of riverine landscape dynamics. Aquat Sci. 64:129140.

Orhan, O,. Ekercin, E, and Dadaser-Celik, F. (2014): Use of Landsat Land Surface Temperature and Vegetation Indices for Monitoring Drought in the Salt Lake Basin Area, Turkey. The Scientific World Journal. 2014, 11.

Penny, D. and Kealhofer, L. (2005): Microfossil evidence of land-use intensification in north Thailand. J Archaeol Sci. 32,69-82.

Piwowar, J. M. and Ledrew, E. F. (2002): ARMA time series modelling of remote sensing imagery: A new approach for climate change studies. International Journal of Remote Sensing. 23: 5225-5248.

Pozdnyakov, D., Korosov, A., Grassl, H. and Pettersson, L. (2005): An advanced algorithm for operational retrieval of water quality from satellite data in the visible. International Journal of Remote Sensing. 26: 2669-2687.

Simav Ö, Şeker DZ. and Gazioğlu C (2013) Coastal inundation due to sea level rise and extreme sea state and its potential impacts: Çukurova Delta case. Turkish J Earth Sci. 22:671-680.

Yalvaç, S. (2016): Detecting Land Subsidence in Konya Closed Basin by Means of GNSS Time Series, University of Selcuk).

Yang, X. and Lu, X. (2014): Drastic change in China's lakes and reservoirs over the past decades. Scientific Reports. 4, Article number:6041.

Yıldırım, U,. Erdoğan, S, and Uysal, M, (2011): Changes in the Coastline and Water Level of the Aksehir and Eber Lakes Between
1975 and 2009. Water Resources Management. 25:941-962. 